\title{
Deconstructing Daniel Speer's Philomela angelica (1688) to Reconstruct Chiara Margarita Cozzolani's Scherzi di sacra melodia (1648)
}

\author{
Marina Toffetti / marina.toffetti@unipd.it \\ Department of Cultural Heritage, University of Padua, IT
}

\begin{abstract}
Starting from the case of six motets for solo voice and basso continuo by Chiara Margarita Cozzolani, originally printed in a collection that has come down to us without the basso continuo part (Scherzi di sacra melodia, 1648) and later reworked and published in a collection (Philomela angelica, 1688) attributed to Daniel Speer, the present article will focus on the problems that emerge when the editor of a musical edition must intervene with the criteria of destructive restoration, which consists in the deconstruction of later reworkings, in an attempt to recover one or more previous musical layers of a work.

The main questions that arise are the following: is it possible to reconstruct the six motets of Chiara Margarita starting from the subsequent reworkings of Daniel Speer? Is this a philologically legitimate operation? And, if so, how can we present the results of this operation in a critical edition?

After dealing with some interdisciplinary and methodological issues, the paper will show how Cozzolani's compositions have informed Speer's subsequent reworkings and how, through the de-construction of the latter, it is now possible to reconstruct a convincing hypothesis of the basso continuo line and to re-propose to modern audiences the compositions of Cozzolani that have not been performed for centuries due to the lack of the basso continuo.
\end{abstract}

\section{Keywords}

Chiara Margarita Cozzolani; Daniel Speer; musical re-elaborations; destructive restoration; critical edition; performance praxis; basso continuo 


\section{Foreword}

The interest in the reconstruction of works of the past that have come down to us incomplete has always accompanied my musicological activity, and I am sure that it can be no coincidence that all critical editions I have edited have involved, to some extent, a work of reconstruction. ${ }^{1}$ In the specific case of Chiara Margarita Cozzolani's Scherzi di sacra melodia, my interest in the possibility of reconstructing the missing part of the basso continuo was born a few years ago, when my colleague and friend Jana Kalinayová-Bartová involved me as a reviewer in the publication of the critical edition, edited by herself, of Daniel Speer's Philomela Angelica. ${ }^{2}$ This is why I am particularly grateful to her for having involved me in this exciting enterprise, from which the present reflections have originated. My hope is that they can contribute to the rediscovery and enhancement of a collection that has fallen into oblivion for centuries due to the lack of the part of the continuo, but certainly deserving to be brought back to the attention of the modern public.

\section{Preliminary remarks}

Although music is a temporal art, the reflections carried out in the field of the restoration of the figurative arts can help to clarify some aspects relevant to the practice of restitution of the musical text.

For those dealing with the history of architecture, a discipline that also studies the transformations made to buildings in the course of their history, it is clear that for long periods it has even been possible to ignore the existence of some ancient buildings, since, at a certain point in their history, they have been incorporated into new buildings. ${ }^{3}$ Not dissimilar situations can occur also in the history of music, and the musical philologist, as a historian of a text (the musical one), is faced with the task of distinguishing the author's variants from those of tradition and trying to return, in a critical edition, one or more texts as close as possible to the last will of the author (or authors).

1 See INGEGNERI, Marco Antonio. Inni a 4 voci (Venezia, 1606). Marina Toffetti (ed.). Lucca: LIM, 2002 (Opera Omnia, Serie I, vol. VIII); ARDEMANIO, Giulio Cesare. Musica a più voci (Milano, 1628). Composizioni per un'azione pastorale in onore di San Carlo Borromeo. Marina Toffetti (ed.). Pisa: ETS, 2012 («Diverse voci...», 11); FRESCOBALDI, Girolamo. Liber secundus diversarum modulationum singulis, binis, ternis, quaternisque vocibus (1627), critical edition and reconstruction of the missing part by Marco Della Sciucca and Marina Toffetti (Monumenti Musicali Italiani, XXVI, Girolamo Frescobaldi, Opere Complete, XI). Milano: Suvini Zerboni, 2014.

2 See Kalinayová-Bartová, J., Zajíček, P., eds. Daniel Speer (1636-1707): Philomela angelica cantionum sacrarum (1688), Musicalia Istropolitana 7/5. Bratislava: Ars Musica, 2014; Kalinayová-Bartová, J., Zajíček, P., eds. Daniel Speer (1636-1707): Philomela angelica cantionum sacrarum (1688), Musicalia Istropolitana 7/1. Bratislava: Ars Musica, 2016.

3 See BELLINI, Amedeo. Il restauro architettonico. Milano: Mondadori, 1978; BROGIOLO, Gian Pietro. Archeologia dell'edilizia storica: documenti e metodi. Como: New Press, 1988. 
Just as in the context of the figurative arts one of the main goals of a restoration consists in safeguarding the visible traces of the history of a building, in the same way in the musicological field one of the main objectives consists in finding the written tracks of the history of a composition, and in returning them in the most coherent possible way within the critical edition (which, in turn, will be translated into audible terms thanks to subsequent musical performances).

Moreover, in the investigation of the history of the successive stratifications, the figurative arts (think for example of a fresco) frequently use preliminary diagnostic investigations aimed at ascertaining the chronological sequence, the content, the structure and the state of conservation of the different pictorial layers. ${ }^{4}$ Similarly, the musical philologist makes a sort of 'critical stratigraphy' of the sources that (in the most fortunate cases) allows us to reconstruct a stemma codicum that will help to distinguish, within a musical construct, the elements belonging to interventions made at different moments.

What distinguishes the results of a restoration from the results of a critical edition (musical or not) is the fact that, in the context of the figurative arts, in the presence of several pictorial layers it is often a matter of deciding which of them deserves to be restored, and therefore 'saved', at the expense of all others, which will instead be destined to be sacrificed forever. ${ }^{5}$ In the case of a musical composition (or a poetic or literary text), on the contrary, the recovery of a layer, that is, a textual level preceding the last available one, does not imply the sacrifice of the others. ${ }^{6}$ The danger you run, if anything, is not to recognize the different textual levels, and therefore to realize the edition of a single composition, when it would be appropriate, as recommended by Gianfranco Contini, to create as many editions as there are texts to be returned. ${ }^{7}$

It is no coincidence that Cesare Segre had described the work of the philologist as a sort of dialysis, of discrimination between the elements attributable to the linguistic system of the author and those attributable to the linguistic system of the later copyists. ${ }^{8}$

4 For some basic information on the stratigraphic method, see HARRIS, Edward C. Principles of archaeological stratigraphy. London: Academic press, 1979, and CARANDINI, Andrea. Storie dalla terra. Manuale di scavo archeologico. Torino: Einaudi, 2000 ( $1^{\text {st }}$ ed.: Bari: De Donato, 1981). On restoration and its cultural meaning see ZANARDI, Bruno. Il restauro: Giovanni Urbani e Cesare Brandi, due teorie a confronto. Milano: Skira, 2009.

5 See DOGLIONI, Francesco. Stratigrafia e restauro: tra conoscenza e conservazione dell'architettura. Trieste: LINT, 1997.

6 Even in the case of the so-called integrative restoration, in the field of the figurative arts an integration can alter or deface the work of art in a definitive way; whereas the reconstruction of a missing voice in an incomplete polyphonic construct will always be only a hypothesis, and as such it will always be possible to replace it with a different or better hypothesis. On this subject see FRESCOBALDI. Liber secundus diversarum modulationum, p. XXXVIII and XC; TOFFETTI, Marina. Restoring a masterpiece. Some remarks on the reconstruction of the missing part in Girolamo Frescobaldi's Liber secundus diversarum modulationum (Rome, 1627). Musica Iagellonica, 2013, vol. 7, p. 5-24.

7 See CONTINI, Gianfranco. Filologia. In Breviario di ecdotica. Torino: Einaudi, 1990 (II reprint), p. 45: “The first caution to consider regards determining whether the text to be reproduced or reconstructed is one or more. [...] It is not licit to mix separate versions: a danger that the Bédierian doctrine of the single manuscript wishes to avoid, a doctrine that, with all the reserves it raised, is nevertheless an attempt to safeguard against composite editions. When the revision of the manuscript tradition highlights only oppositions of adiaphorous variants, different draftings (by the author or not) should be taken into account, which must become the object of just as many editions."

8 See SEGRE, Cesare. Avviamento all'analisi del testo letterario. Torino: Einaudi, 1985, p. 376-377: “A text is 
A fortiori, such an approach may prove fruitful in cases where we know for sure that a composer has subsequently reworked a composition that had already been completed (and sometimes even published) by another composer.

\section{Deconstruction and reconstruction in music}

Having said this, we can now tackle some issues that are more closely related to the reworkings in the history of music: how did this reworking take place? Do the subsequent reworkings allow you to recognize the original composition? And what do they tell us about the musical characteristics of the previous composition?

Although they are not comparable to the successive alterations of buildings that occur in the history of architecture, also in the history of music there are numerous cases of successive alterations, made by the same composer or by different composers and dictated by new aesthetic or functional needs of various nature. ${ }^{9}$ In each situation it is a question of distinguishing the nature of the re-elaboration. Sometimes these are relatively minor variations, as happens when a composition previously conceived for an instrument is simply adapted so that it can be performed by another instrument. In other circumstances the structure of the composition remains substantially unaltered, but the orchestration is transformed, adding or eliminating vocal and/or instrumental parts.

A well-known case of subsequent reuse of pre-existing musical material is that of the liturgical melodies of the so-called Gregorian chant reused in a polyphonic context. Ever since the origins of Western written polyphony the liturgical chant, originally monodic in nature, has been reused for centuries within polyphonic compositions. If properly interrogated, the latter can therefore tell us something about the characteristics assumed by the liturgical melodies at the time when they were incorporated into the polyphonic constructs.

In an article on Palestrina's polyphonic hymns, Giacomo Baroffio has addressed some crucial issues for the reflection on the re-use of pre-existing musical materials: what can the polyphony of Palestrina reveal to us about the Gregorian chant of his era? Which liturgy is reflected in its polyphonic hymns? What melodic version was at the base of his hymns? And what can they tell us about the performance practice of Gregorian chant in his day? ${ }^{10}$ The only way to answer these questions will be that of 'deconstructing' the

a linguistic structure that gives rise to a system. Every copyist has his own linguistic system, which comes into contact with that of the text over time in a tradition. [...] The compromise between the system of the text and that of the copyist brings about a diasystem. The emendatio is a sort of dialysis that separates the elements of the mediation system from the basic system."

9 On this topic see CARACI VELA, Maria. Intertestualità e arte allusiva. In La filologia musicale. Istituzioni, storia, strumenti critici. Lucca: Libreria Musicale Italiana, vol. II, 2009, p. 117-173.

10 BAROFFIO, Giacomo Bonifacio. Palestrina e il canto gregoriano: l'innodia. In Palestrina e la sua presenza nella musica e nella cultura europea dal suo tempo a oggi. Atti del II Convegno Internazionale di Studi Palestriniani. Lino Bianchi - Giancarlo Rostirolla (eds.). Palestrina: Fondazione G. P. da Palestrina - Centro Studi Palestriniani, 1991, p. 23-26: 24. 
polyphonic hymns in order to understand which voice of the polyphonic hymns has been entrusted with the traditional liturgical melody (always the same voice, or different voices?); how was it presented (in the original tone, or in a transposed tone?); how was it used (faithfully, or with melodic variations?).

Something similar can be said about the polyphonic hymns of Marc'Antonio Ingegneri - very well known as the maestro of Claudio Monteverdi. ${ }^{11}$ We know that an innarium dating back to the years in which Ingegneri was active as chapel master of the cathedral of Cremona was modified in those years; ${ }^{12}$ and that Ingegneri had extracted the liturgical melodies used in his polyphonic hymns from the second draft of this innarium, also adopting their rhythmic profile. ${ }^{13}$

If in these cases the examination of successive compositions can reveal only certain characteristics of the musical material on which they are based, in other circumstances it is possible to recover pre-existing compositions (or at least to formulate reliable hypotheses on their original structure) starting from their subsequent re-elaborations. The case of Rusca's Sacri concerti (Milan, 1630) is emblematic in this regard. Claudia Rusca (1593ca-1676), a nun who lived at the convent of Santa Caterina in Brera di Milano, is known as the author of a collection of sacred and instrumental compositions for one to five voices and organ. The only copy of this collection, previously kept at the Biblioteca Ambrosiana in Milan, was destroyed in 1943 during an air raid. Between 1940 and 1950 Giorgio Federico Ghedini had made a re-elaboration for solo, choir and chamber orchestra of some (11) of these compositions. For about sixty years it was thought that of the compositions of Claudia Rusca it was possible only to formulate a hypothesis of reconstruction based on the deconstruction of the reworkings of Ghedini. ${ }^{14}$ The subsequent discovery, in 2001-2002, of a photographic reproduction of the original edition finally made it possible to study and perform the original compositions. ${ }^{15}$

11 See Ingegneri, Marc'Antonio, in Grove ${ }^{2}$, vol. 12, p. 380-382.

12 TOFFETTI, Marina. Il testo nel tempo: le modifiche apportate allo Psalterium et Hymnarium del Tesoro della Cattedrale di Cremona sullo sfondo della prassi esecutiva del gregoriano tardo. Rivista Internazionale di Musica Sacra, 2003, 2, p. 123-148; TOFFETTI, Marina. Inni da un Salterio-Innario cremonese. In Cantus fractus italiano. Un'antologia. Marco Gozzi (ed.). Hildesheim-Zürich-New York: Georg Olms Verlag, 2012 (Musica Mensurabilis, 4), p. 233-246.

13 INGEGNERI. Inni a 4 voci (Venezia, 1606), par. 3, p. XX-XXIII (on the origin of the liturgical melodies used by Ingegneri); par. 4, p. XXIII-XXXII (on the polyphonic use of liturgical melodies); TOFFETTI, Marina. L'impiego delle melodie liturgiche tradizionali nella polifonia del tardo Rinascimento: il caso degli inni di Marc'Antonio Ingegneri (Venezia, 1606). In Il canto piano nell'era della stampa. Atti del convegno internazionale di studi (Trento, Castello del Buonconsiglio - Venezia, Fondazione Levi, 9-11 ottobre 1998). Giulio Cattin - Danilo Curti-Feininger - Marco Gozzi (eds.). Trento: Provincia autonoma di Trento - Servizio Beni librari e archivistici, 1999, p. 161-177.

14 A publication with the reconstructed original versions of Rusca's Sacri Concerti ed. by M. J. Wasmer and R. L. Kendrick had been announced as forthcoming in KENDRICK, Robert L. Celestial Sirens: Nuns and their Music in Early Modern Milan. Oxford: Oxford University Press, 1996, p. 499.

15 KENDRICK, Robert L. I mottetti di Claudia Rusca. In Barocco Padano 3. Alberto Colzani - Andrea Luppi - Maurizio Padoan (eds.). Como: AMIS (Antiquae Musicae Italicae Studiosi), 2004, p. 425-445; KENDRICK, Robert L. Traditions and Priorities in Claudia Rusca's Motet Book. In Female Monasticism in Early Modern Europe. An Interdisciplinary View. Cordula van Wyhe (ed.). Burlington: Ashgate, 2008, p. 97-124. 


\section{Daniel Speer's Philomela angelica and Chiara Margarita Cozzolani's Scherzi di sacra melodia}

The case of the motets of Chiara Margarita Cozzolani presents some similarities with that of the Sacri Concerti of Claudia Rusca. In this case too, in fact, the subsequent reworking of a previous work may allow a hypothesis of reconstruction of the original compositions.

Chiara Margarita took her vows in 1620 in the Benedictine convent of Santa Radegonda in Milan. In the years 1640-1650 she published four music collections (Primavera di fiori musicali, 1640, lost; ${ }^{16}$ Concerti sacri, 1642; Scherzi di sacra melodia, 1648; and Salmi a otto, 1650). ${ }^{17}$ While very little remains of the ancient convent (see Figure 1), ${ }^{18}$ which became famous for its nuns singing 'like angels' ${ }^{19}$ of both copies of the Scherzi by Chiara Margarita Cozzolani only two copies of the part-book of the Cantus have been preserved, kept in Bologna and in Wrocław. ${ }^{20}$ The canto-part was referred to as "parte che canta separata" in three lists of works of the publisher Alessandro Vincenti issued in 1649, 1658 and $1662 .{ }^{21}$ We cannot know when the part-books of the basso continuo disappeared. It

16 According to Robert Eitner, a copy of it, lacking the tenor part, was kept in Berlin Gymnasium zum grauen Kloster. See EITNER, Robert. Biographisch-bibliographisches Quellen-Lexikon, vol. 3. Leipzig: Breitkopf \& Härtel, 1900, p. 91-92; this same copy is also mentioned in Zur Feier des Wohlthätenfestes im Berlinischen Gymnasium zum grauen Kloster. Berlin, 1856.

17 See KENDRICK, Robert L. Chiara Magarita Cozzolani. In Grove², vol. 6, p. 636-637; KENDRICK, Robert L. The Traditions of Milanese Convent Music and the Sacred Dialogues of Chiara Margarita Cozzolani. In The Crannied Wall: Women, Religion and the Arts in Early Modern Europe. Craig A. Monson (ed.). Ann Arbor: University of Michigan Press, 1992, p. 211-234.

18 After a partial demolition of the Benedictine nunnery (1781), the Teatro Santa Radegonda was built, inaugurated in 1819, renovated in 1851 and demolished between 1882 and 1883; later, until 1921, the area was occupied by a thermoelectric power station, the first of its kind in Europe; and finally this was replaced by the Teatro Odeon (today: The Space Cinema Odeon). Further information and historical photographs can be found on the website http://www.lombardiabeniculturali.it/ricerca/?q=santa+radegonda (accessed 06/02/2018).

19 "per non saper distinguere in S. Radegonda Monastero di Monache, se quelle voci, che cantavano erano di qua giù, o celesti. Cantarono una Regina Celi, che ben mostrarono haver imparato da gli Angeli”. See Sebastiano LOCATELLI, 'Viaggio in Francia' [1664]. Cited in KENDRICK. Celestial Sirens, p. 460.

20 RISM A/I C 4361: I Bc; PL WRu. The copy preserved in Wrocław, together with another two collections of Cozzolani (1642 and 1650), was part of the Bibliotheca Sartoriana, the rich music collection assembled by Daniel Sartorius (1612-1671) and later incorporated into the Bibliotheka Rhedigeriana of Wrocław. In the oldest surviving catalogue of this collection, compiled by Siegfried Wilhelm Dehn, curator of the music collections of the Königliche Bibliothek in Berlin (Catalogus der auf der Elisabeth-Bibliothek befindlichen Musicalien (Rhedigerische Bibliothek), 1853) two copies of Cozzolani's Scherzi di sacra melodia are listed. See JEŻ, Tomasz. Danielis Sartorii Musicalia Wratislaviensia. Warsaw: Wydawnictwo Naukove Sub Lupa, 2017 (Fontes Musicae in Polonia, A/I), p. 62-63, 86, 167-168, 344-345. According to Emil Bohn, the print should consist in a set of two partbooks in fol.: voce, and part. See BOHN, Emil, ed. Bibliographie des Musik-Druckwerke bis 1700 welche in der Stadtbibliothek, der Bibliothek des Akademischen Instituts für Kirchenmusik und in der Königlichen- und Universitätsbibliothek zu Breslau aufbewahrt werden. Berlin: A. Cohn, 1883.

21 1649, 1658, 1662. In the catalogue from 1649 Cozzolani's Scherzi are listed just once, as the last item of the section devoted to the "Motetti, e Concerti con il suo Basso per sonar". In the following two catalogues the same collection is listed twice: the first time among the "Motetti a voce sola", the second among the "Motetti, e Concetti 
is probable, however, that these motets have not been performed for several centuries due to the lack of the basso continuo. However, six motets (of the twelve included in the collection) would reappear in a reworked form in an anonymous collection (but attributable to Daniel Speer) published forty years later. ${ }^{22}$
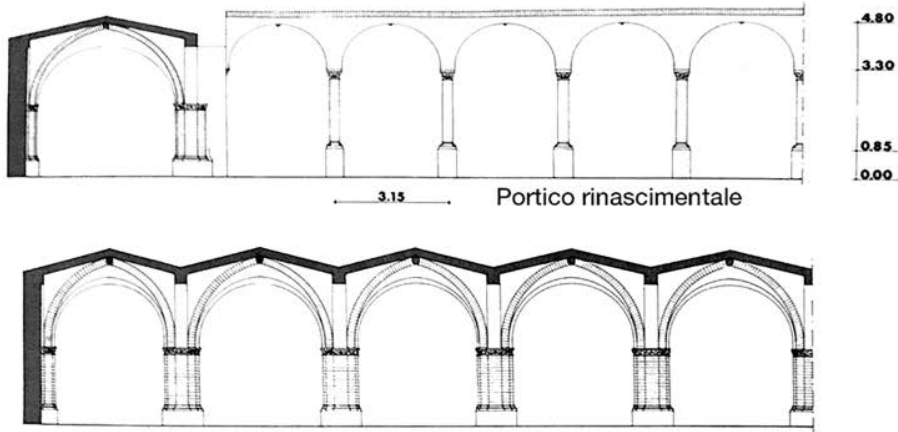

Portico gotico

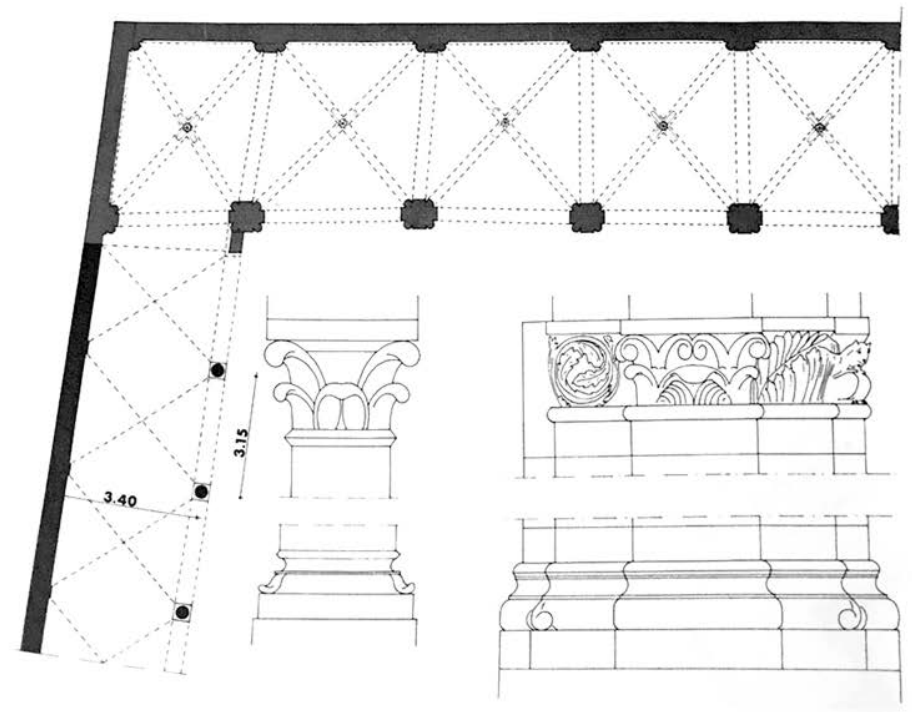

Fig. 1 Details of the cloister of Santa Radegonda

con il suo Basso per sonar". See MISCHIATI, Oscar. Indici, cataloghi e avvisi degli editori e librai musicali italiani dal 1591 al 1798. Firenze: Olschki, 1984, p. 174, 194, 198, 222, 226.

22 The motets by Cozzolani re-elaborated by Daniel Speer are the following: O Iesu meus amor, Venite qui esuritis, Venite gentes, Venite ad me omnes, O praeclara dies and Quis mihi det calicem bibere? (Quis mihi det bibere in Speer's version). See KALINAYOVÁ-BARTOVÁ, Jana. Italian Musical Inspirations in Daniel Speer's Philomela angelica cantionum sacrarum collection. In: Kalinayová-Bartová, J., Zajíček, P., eds. Daniel Speer (16361707): Philomela angelica, Musicalia Istropolitana 7/1. 
What appears evident even at first sight is that Speer's re-elaborations responded first of all to a change of taste: at forty years from their appearance, the sacred concertos of Cozzolani (and, more in general, the small-scale motets composed in various parts of the peninsula in the late sixteenth and early seventeenth century, widely circulated in various parts of Europe since the second decade of the seventeenth century), while continuing to exert a charm that justifies their survival and reworking, must have sounded somehow too essential for the modern public to the north of the Alps. Hence the decision to add a certain number of stringed instruments to make the harmonic accompaniment timbrically richer.

Adding violin parts to Italian sacred concertos for voices and continuo was a wellknown procedure going back to the earlier German practice of adaptation of Italian music. Barbara Wiermann describes this practice as "eine genuine deutsche Besetzungskomponente [...], die vermutlich auf Praetorius zurückgeht." ${ }^{23}$ In fact Michael Praetorius, in the third book of his Syntagma musicum (1619), had already proposed to supply an additional capella fidicina in order to make Italian music more attractive to German listeners and also "to fill out the harmony", and explained: "some among us Germans are still not accustomed to the new Italian invention, where only one concertato voice, or two or three, sing with the organ or regal, and, still unaccustomed to it, think that it sounds too thin, and does not especially please or give pleasure to those who do not understand music." ${ }^{44}$ The capella fidicina parts could be played on different instruments, but preferably "stringed instruments, such as violins, lutes, harps, and all the others, particularly with viols de gamba, or, lacking them, one can have viols da braccia." 25

As Praetorius very well explains, the capella fidicina had a close connection with an extended realization of the basso continuo figuring: "The capella would also be useful to organists who are not trained and inexperienced in composition, and therefore are lost in throughbass right at the start; sometimes then it would be easier to write out all the middle voices or parts (which usually are not provided in such concerti) in their tablatures, rather than that they should have to speculate whether or not fourths and fifths and thirds should be played. Therefore I have in several of these compositions called them Capella pro organo, also pro Testudine, Theorbo, etc. "26 (An example of this procedure can be found also in Speer's motet O Iesu meus amor, as shown by the measures highlighted in yellow in Ex. 1).

In her doctoral thesis on Gustav Düben and the musical repertory of Swedish court musicians, Maria Schildt examines the vast repertoire of the compositions, mostly of Italian origin, of the so-called Düben Collection kept at the Carolina Rediviva Library in Up-

23 WIERMANN, Barbara. Die Entwicklung vokal-instrumentalen Komponierens im protestantischen Deutschland bis zur Mitte des 17. Jahrhunderts. Göttingen: Vandenhöck \& Ruprecht, 2005 (Abhandlungen zur Musikgeschichte, 14), p. 53. On this same topic see also WOLLNY, Peter. Studien zum Stilwandel in der protestantischen Figuralmusik des mittleren 17. Jahrhunderts. Beeskov: Ortus, 2016 (Forum Mitteldeutsche Barokmusik, 5), p. 330-398: Aneignungen: Parodie, Imitatio und Aemulatio.

24 PRAETORIUS, Michael. Syntagma musicum. Vol. 3 , Wolfenbüttel: Holwein 1619, p. 115-116. Engl. transl.: Readings in the History of Music in Performance. Carol Mac Clinton (ed.). Bloomington, 1979, p. 147.

25 PRAETORIUS, op. cit., p. 115-116. Readings, p. 148.

26 PRAETORIUS, op. cit., p. 117. Readings, p. 148. 
psala. An entire chapter of her dissertation is devoted to the northern European practice of adding independent instrumental parts (either obbligate or optional) to vocal music of Italian origin. ${ }^{27}$ Such a practice was very widespread: just think of some compositions by Giacomo Carissimi, originally conceived for solo voices and continuo, that in the German and Dutch prints were provided with independent instrumental (mainly string) parts. Schildt examines several cases, including the motet Sustinuimus of Carissimi, with 4 viole added by Balthasar Erben, ${ }^{28}$ and the motet Salve Regina of Giovanni Rovetta, of which there is a version with a different text and with the addition of instrumental parts supplied by Franz Tunder. Such 'stuffing' intervention operated by Speer on the compositions of Cozzolani is therefore far from being an exceptional case, but, on the contrary, is part of a tendency towards widely diffused re-elaboration.

In an attempt to grasp the specificity of Speer's interventions, we will first try to understand how he 'reacted' to Cozzolani's motets. What is evident is that he considered them worthy of being re-proposed to his contemporaries. It is significant, however, that, according to Speer, this enhancement should go through an operation of updating and adaptation to modern taste. The choice of adding four stringed instruments clearly responds to the desire to increase the impact of the original compositions, giving them a richer and varied timbre, evidently more suited to the tastes of his contemporaries. As it has already been remarked, the insertion of instrumental episodes with the function of an introduction and of instrumental refrains between one vocal episode and the next contributes to give Cozzolani's compositions a more marked sense of formal architecture and a greater structural quadrature, typical of the most mature Baroque compositions. ${ }^{29}$ We must add that such additions have also somehow betrayed the freer and sometimes less symmetrical character of the original compositions.

But Speer's re-elaboration also involves other consequences. In addition to the compositional differences, which can be seen on the paper by comparing the structural features of the two compositions, some differences concerning the dimension of the performance practice, and thus destined to manifest themselves only in the performance, must also be considered. In fact, if in performing Cozzolani's motets the singer could manage the agogical aspect in complete freedom, certain that the continuist seated on the organ or the harpsichord would adapt to her estrus, in performing Speer's re-elaboration, in correspondence of the sections in which four instrumental parts have been introduced with a function of harmonic filling, the voice is forced to proceed with a greater rhythmic regularity, thus depriving the original composition of its most vital agogic vein. As happens every time a work of art is adapted to functional or aesthetic needs occurring

27 SCHILDT, Maria. Gustav Düben at work. Musical repertory and practice of Swedish court musicians $1663-1690$. Uppsala: Uppsala Universitet, 2014 (PhD. diss., University of Uppsala, 2014), p. 345-351. Schildt also quotes the passages from Praetorius's Syntagma musicum cited in the present article.

28 On this same topic see also BACCIAGALUPPI, Claudio. Carissimi "farcito": esempi di ricezione e di diffusione nel Nord e nell'Est europeo. In L'opera musicale di Giacomo Carissimi. Fonti, catalogazione, attribuzioni. Atti del convegno internazionale di studi Roma, 18-19 novembre 2005. Daniele Torelli (ed.). Roma: Accademia Nazionale di Santa Cecilia, 2014 (L'arte Armonica. Serie III, Studi e testi, 14), p. 33-54.

29 See Jana Kalinayová-Bartová's article on the p. 87-104. 


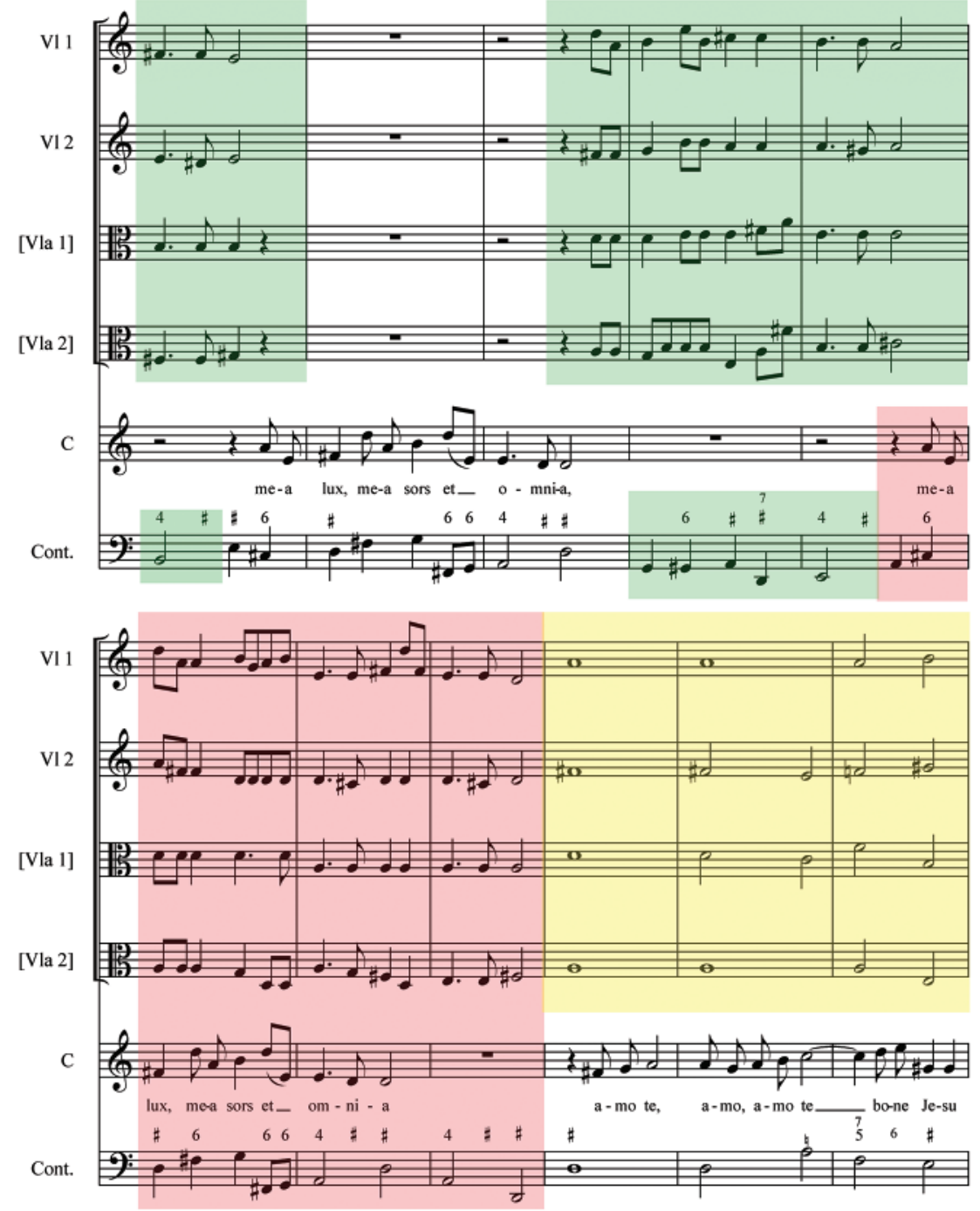

Ex. 1 Daniel Speer, O lesu meus amor, bars 30-40

at a later time, in this case too something has been gained, i.e. greater richness and timbric variety in Speer's re-elaboration, but something has gone irremediably lost, i.e. the agogical freedom of the accompanied monody of Cozzolani's original motet.

As regards the texture of the re-elaborations, analyzing Speer's new compositions one observes that he has not introduced the instruments everywhere (and in fact some episodes of his re-elaborations continue to be entrusted to the voice supported only by the basso continuo); on the other hand he did not use the instruments only in the sections in which the voice sings, with a filling function, but also in other, new sections of free invention. These are short refrains that resume (or anticipate), with slight changes, 
melodic and harmonic material already presented by the voice or the bass, or destined to reappear in the voice or in the bass. It follows that Speer's re-elaborations modify the original compositions also at a diachronic level (and in fact they are much longer than the first), ${ }^{30}$ while in the synchronic dimension they are more varied than the original ones. In fact, while Cozzolani's concertos, with the only exception of a few short passages entrusted only to the basso continuo, presented a single texture (voice and continuo) from the beginning to the end of the composition (which could be monotonous for Speer's contemporaries), Speer's re-elaborations 'entertain' the listener with a more varied texture, in which episodes for solo voice and continuo (corresponding to the original) alternate with episodes for voice, basso continuo and instruments, and with exclusively instrumental episodes (see Ex. 1).

Let's now look more closely at the treatment reserved for the first of Cozzolani's motets, O Iesu meus amor, in the re-elaboration of Speer. In Table 1 the exclusively instrumental episodes are highlighted in yellow, those for voice and instruments are shown in red, and those in which the original texture for voice and basso continuo is kept in light blue; the text portions highlighted in gray correspond to the sections in triple time (see Tab. 1).

\begin{tabular}{|c|c|c|c|}
\hline & Cozzolani & \multicolumn{2}{|c|}{ Speer } \\
\hline & bars & bars & Scoring \\
\hline & - & bb. 1-20 & Instruments \\
\hline \multirow[t]{2}{*}{ O lesu meus amor, mea vita, meus cor et omnia, } & bb. 1-8 & bb. $21-28$ & solo voice \\
\hline & - & bb. $28 \|-30$ & Instruments \\
\hline \multirow[t]{2}{*}{ mea lux, mea sors et omnia, } & bb. 9-11 & $30 ॥-32$ & solo voice \\
\hline & - & $32 \|-34$ & Instruments \\
\hline \multirow[t]{2}{*}{ mea lux, mea sors et omnia. } & - & $34 \|-36$ & voice + instr. \\
\hline & - & $36 \|-37$ & Instruments \\
\hline Amo te, bone lesu & bb. $12-14$ & bb. $38-40$ & voice + instr. \\
\hline Vel si me fugias sequar te & bb. $15-18$ & bb. $41-44$ & voice + instr. \\
\hline \multirow[t]{2}{*}{ Vel si me crucies laudabo te } & bb. $19-22$ & bb. $45-48$ & solo voice \\
\hline & - & b. 49 & Instruments \\
\hline Vel si me diligas & bb. $23-24$ & bb. $50-51$ & voice + instr. \\
\hline \multirow[t]{2}{*}{ amabo te, amabo te. } & bb. $25-28$ & bb. $54-55$ & solo voice \\
\hline & - & bb. $55-58$ & Instruments \\
\hline Ostende, ostende mihi faciem tuam & bb. 29-31 & bb. 59-61 & voice + instr. \\
\hline \multirow[t]{2}{*}{ et salvabis me, salvabis me. } & bb. $32-35$ & bb. 62-63 & solo voice \\
\hline & - & b. 64 & instruments \\
\hline Ostende, ostende mihi faciem tuam & - & bb. $65-68$ & voice + instr. \\
\hline \multirow[t]{2}{*}{ et salvabis me, salvabis me. } & - & bb. $69-70$ & solo voice \\
\hline & - & bb. 70-72 & instruments \\
\hline
\end{tabular}

30 As we can notice (see Table 1), the motet $O$ Iesu meus amor in Cozzolani's version has a duration of 206 bars in the modern transcription, while Speer's version has a duration of 257 bars, which means that Speer has added 51 bars (about 20 percent of the total duration) including instrumental sonatas, refrains, short cadenzas and the like. 


\begin{tabular}{|c|c|c|c|}
\hline & \multirow{2}{*}{$\frac{\text { Cozzolani }}{\text { bars }}$} & \multicolumn{2}{|c|}{ Speer } \\
\hline & & bars & Scoring \\
\hline \multirow[t]{2}{*}{ Me respice, me respice et beabis me. } & bb. $36-43$ & bb. $72-79$ & voice + instr. \\
\hline & - & bb. 79-81 & Instruments \\
\hline $\begin{array}{l}\text { Quo fugis quo fugis, quo fugis dilecte mi, quo fugis, o mi } \\
\text { lesu, o dilecte mi, quo fugis ne recedes, heu, meum cor, } \\
\text { heu, meum cor, meum cor, meum cor, vita fugit en umbra } \\
\text { mortis caecavit nox, heu, miserum me. }\end{array}$ & bb. $45-60$ & bb. 81-96 & solo voice \\
\hline $\begin{array}{l}\text { Converte, converte faciem tuam, o mi lesu } \\
\text { converte, converte, converte, converte faciem tuam o, } \\
\text { o mi lesu, o, o mi lesu. }\end{array}$ & bb. 61-83 & bb. 97-119 & voice + instr. \\
\hline $\begin{array}{l}\text { Revertere, revertere, revertere, revertere, heu, heu mi } \\
\text { lesu perimis me. }\end{array}$ & bb. $85-88$ & bb. 119-124 & solo voice \\
\hline \multirow[t]{2}{*}{$\begin{array}{l}\text { Veni, veni, veni, veni, } \\
\text { amo te, amo te }\end{array}$} & bb. 89-96 & bb. $125-132$ & solo voice \\
\hline & - & bb. $132-135$ & Instruments \\
\hline Mea felicitas, mea lux, & $\begin{array}{l}\text { bb. 97-100 } \\
\text { [Allegro] }\end{array}$ & bb. $135-139$ & voice + instr. \\
\hline \multirow[t]{2}{*}{ redeas, redeas amo te, amo te } & bb. 101-106 & bb. $140-145$ & solo voice \\
\hline & - & bb. $145-148$ & Instruments \\
\hline $\begin{array}{l}\text { Veni, veni, veni, veni } \\
\text { meum cor, } \\
\text { veni, veni, veni,veni, } \\
\text { mea lux, mea sors, } \\
\text { o, ০, ০, o, veni, veni, o veni, veni, veni, }\end{array}$ & bb. $107-130$ & bb. 149-175 & voice + instr. \\
\hline veni, veni, veni meum cor, & bb. 131-133 & bb. $173-175$ & solo voice \\
\hline [veni, veni mea lux] & bb. $134-136$ & bb. 176-178 & instruments \\
\hline Veni, veni meum cor [mea sors] & bb. 137-139 & bb. 179-181 & solo voice \\
\hline [veni, veni, veni] & bb. $140-142$ & bb. $182-184$ & Instruments \\
\hline \multirow{2}{*}{$\begin{array}{l}\text { O, o, o, o } \\
\text { veni, o veni, veni, veni, veni, veni, veni, veni, veni }\end{array}$} & bb. 143-151 & bb. 184-193 & solo voice \\
\hline & - & bb. 193-196 & instruments \\
\hline Bone lesu, mea lux, mea sors & bb. $152-157$ & bb. 197-202 & solo voice \\
\hline \multirow[t]{2}{*}{ Veni, veni, veni, veni, amo te, amo te. } & bb. $158-164$ & bb. 203-209 & solo voice \\
\hline & - & bb. 209-212 & Instruments \\
\hline $\begin{array}{l}\text { Mea iucunditas, mea felicitas, } \\
\text { mea iucunditas, mea felicitas. }\end{array}$ & $\begin{array}{l}\text { bb. 165-172 } \\
\text { [Allegro] }\end{array}$ & bb. 213-220 & voice + instr. \\
\hline \multirow[t]{2}{*}{$\begin{array}{l}\text { Veni, veni, veni, veni, amo te, } \\
\text { amo te. }\end{array}$} & bb. $173-180$ & bb. 221-228 & solo voice \\
\hline & - & bb. $228-231$ & Instruments \\
\hline $\begin{array}{l}\text { Bone lesu, dulcis lesu, care, care lesu, } \\
\text { bone lesu, dulcis lesu, care, care lesu, } \\
\text { amo, amo, amo te, } \\
\text { amo, amo, amo te, amo te. }\end{array}$ & bb. 181-206 & bb. $232-257$ & voice + instr. \\
\hline
\end{tabular}

Table 1

The initial instrumental introduction (bars 1-20), with its own phraseological quadrature and based on motifs destined to reappear in the cantus part, presents stylistic features quite far from those of the original composition of Cozzolani. For those with 
a minimum familiarity with the style of the first half of the seventeenth century, the first phrase of the voice provokes a certain surprise: the impression gained is that of passing ex-abrupto from one stylistic horizon to another. An identical impression is produced by the short instrumental refrains that repeat the motivic fragments of the voice in a sort of peroratio. However, thanks to the measure of Speer's interventions such effect of 'clash of styles', where perceptible, contributes, if anything, to the interest of the listener who is stylistically more aware.

In summary, Speer's interventions that we can verify in the absence of the basso continuo part can be schematized as follows (proceeding from those, more macroscopic, that involve the structure - and the texture - of the composition, to those of a lighter entity):

1. addition of instrumental sections (sonatas, short episodes, single cadenzas) entrusted to four string instruments supported by the continuo (see Ex. 1, b. 30 and bb. 32-34; see the bars highlighted in green);

2. sporadic addition of fragments entrusted to the solo voice supported by the continuo, with or without instrumental ripieni (see Ex. 1, bb. 34-37; see the bars highlighted in red);

3. addition of instrumental harmonic fillings to episodes for voice and basso continuo (see Ex. 1, bb. 38-40; see the bars highlighted in yellow);

4. suppression of some short passages (see Ex. 2, showing a passage of Cozzolani's motet that was suppressed in Speer's re-elaboration).

Besides these interventions, it is also necessary to consider the modification of the mensural indications (the $\boldsymbol{c}$ used by Cozzolani becomes $\mathbf{c}$ in the compositions of Speer, the 3 used by Cozzolani often becomes $\mathbf{3} \mathbf{2}$ in Speer's reworkings), slight (and not always convincing) changes to the placement of the text under the notes and sporadic textual variants. ${ }^{31}$ Beyond that, we can assume that Speer could have introduced some changes to the basso continuo line. In attempting to reconstruct the bass part of Cozzolani's motets, it will thus be necessary to retrace all the phases of Speer's work backwards:

1. eliminating the instrumental sections;

2. eliminating the added vocal and instrumental sections;

3. removing the harmonic filling entrusted to the instruments;

4. formulating hypotheses of reconstruction of the part of the basso continuo in the rare suppressed passages (see Ex. 2a, 2b, 2c);

and also restoring the mensural indications of the original, adapting the text to the music according to the indications of Cozzolani and restoring, where possible, the original text. In addition to that, we will have to understand if and at what points Speer may have modified the part of the continuo, and make assumptions about its original form.

31 See, for example, the text of the Cozzolani's motet Iesu meus amor "vel si non diligas, amo te", which in Speer's re-elaboration becomes "vel si me diligas, amabo te". 


\section{The recovering of the basso continuo line and its presentation within the critical edition}

With regard to the basso continuo line, it is first of all necessary to keep in mind that the punctual comparison between the cantus part of Cozzolani's motets and that of Speer's subsequent re-elaborations showed how the latter, in the corresponding sections, has taken up the vocal part of his model without making substantial changes to it. Of course we do not know how he behaved towards the continuo line (which has been lost), but we see no reason why he should behave in such a respectful manner towards one voice, while reserving a different treatment to the other. For this reason we will start from the assumption that the bass of Speer corresponds substantially to that of Cozzolani, with the exception of the rare cases in which we can assume that Speer had to introduce slight changes to the bass line (especially in the caesura between the episodes taken from the original composition and those added by him), and of the even rarer cases in which he suppressed short sections of the original composition.

In the following example, taken from the motet Venite gentes, Speer eliminated the final part of an episode of Cozzolani's original motet (lasting three bars in the modern transcription and corresponding to the words "Venite, properate, currite, currite, currite, currite"). In that passage a completely hypothetical reconstruction of the basso continuo is necessary, for which different solutions can be suggested (among the following hypothesis, the final one seems to be the most convincing).
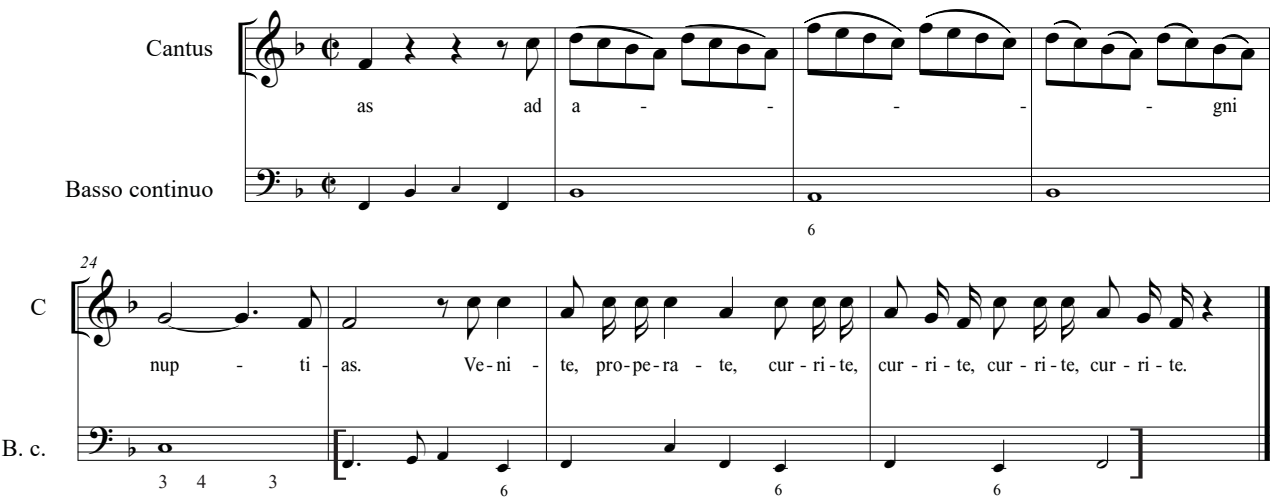

Ex. 2a 

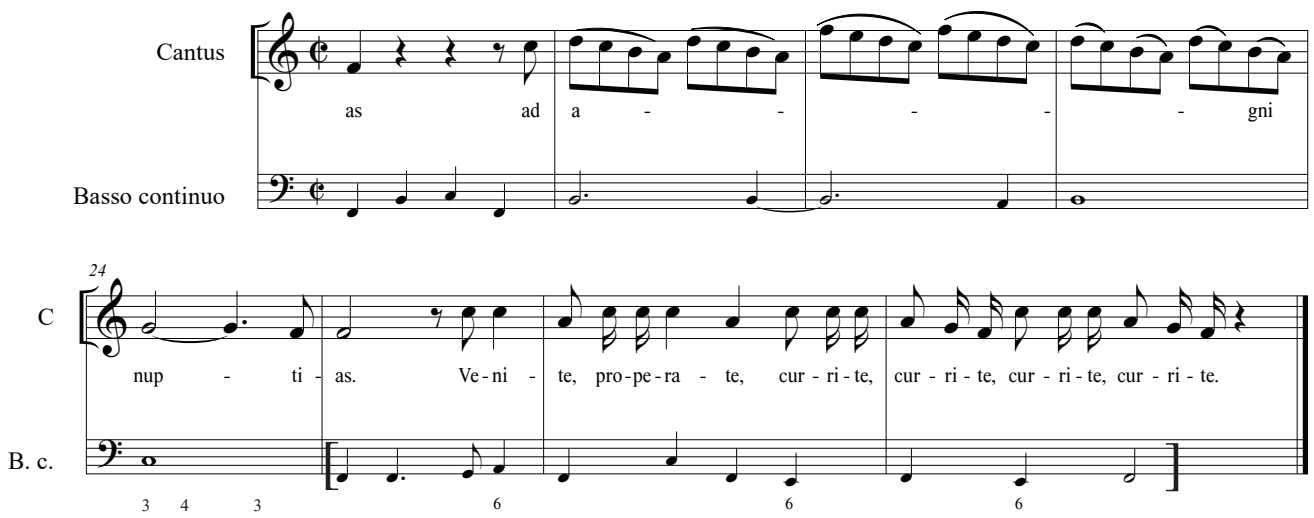

Ex. 2b

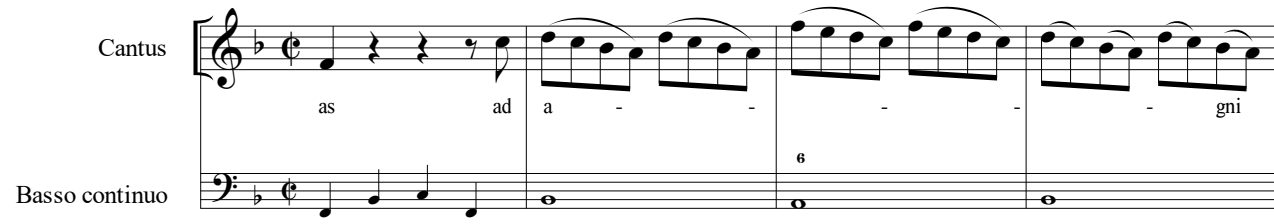

$\mathrm{C}$

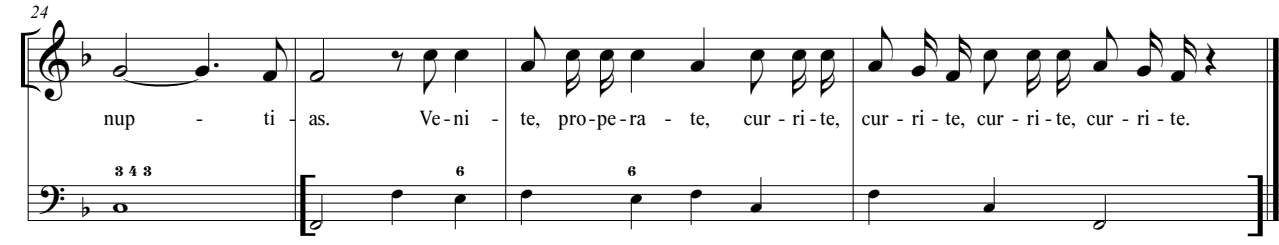

Ex. 2c

Chiara Margarita Cozzolani, Venite gentes, bars 20-27:

three alternative hypotheses of reconstruction of the basso continuo line in a passage of Cozzolani's motet suppressed in the re-elaboration of Speer

The next example shows instead a case in which we can presumably recover Cozzolani's basso continuo, taking it back from Speer's re-elaboration. In this passage the surviving cantus part has many long rests, in correspondence of which it is assumed that the continuist should introduce a rather elaborate (and probably imitative) realization of the bass line, able to 'fill' the span of the rests of the cantus intertwining a dialogue with the voice. In such passages it is probable that the re-elaboration of Speer, while maintaining the part of the bass unaltered, had simply made explicit what was implicit in the original line of the continuo. ${ }^{32}$

32 EITNER. Quellen-Lexikon, p. 91-92. 

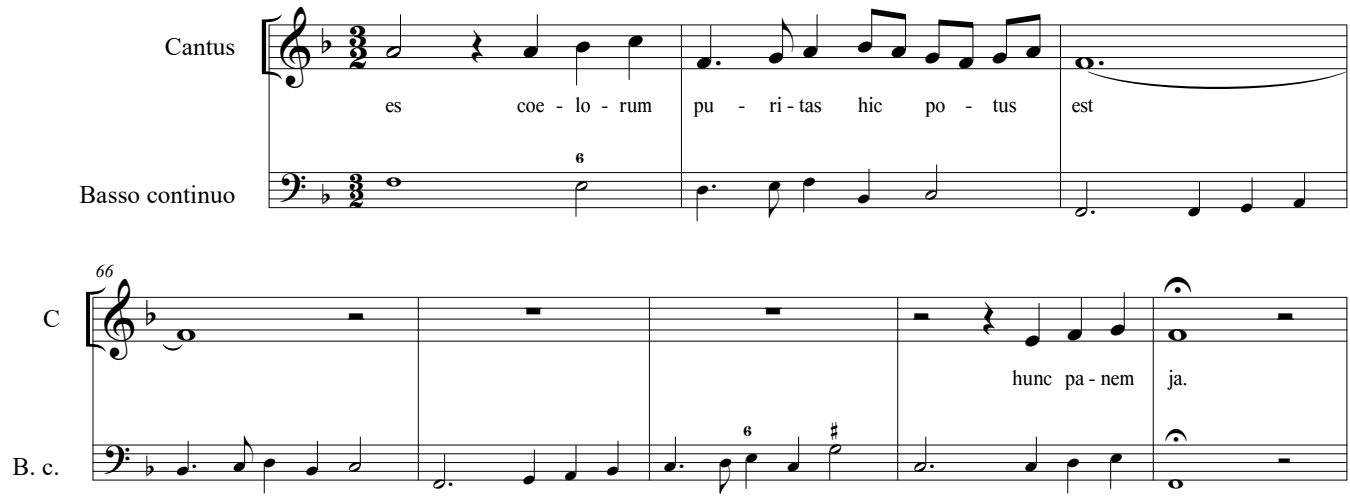

Ex. 3

Chiara Margarita Cozzolani, Venite gentes, bars 63-69

reconstruction of Cozzolani's basso continuo line based on Daniel Speer's re-elaboration

Regardless of the possible slight adaptations mentioned above (which, as already stated, must have been very sporadic), and notwithstanding with the very rare suppressions of some isolated fragments of Cozzolani's original motets, the basso continuo line of Speer's re-elaboration not only 'works' perfectly as a support for the surviving voice, but is also very similar to the continuo lines that we find in the Italian musical production of the mid-seventeenth century. ${ }^{33}$

According to Robert Eitner, a manuscript copy of the bass part of one of the motets from this collection (Venite gentes) was kept in Könisgberg (now Kaliningrad). ${ }^{34}$ Unfortunately this manuscript (searched in vain by Robert L. Kendrick and myself) ${ }^{35}$ is no longer available, which is why we cannot even establish whether it is (or was) a descriptus (in which case we would not have the certainty that the copyist had copied his antigraph faithfully), or a copy prepared for the print. In any case, even if this manuscript copy would reappear, and even if it were identical to the basso continuo line employed by Speer, this would not prove that Speer had kept unchanged the part of the continuo in all Cozzolani's motets he reworked. Vice versa, if the possibly conserved basso continuo was different from that used by Speer, this would not prove that Speer had intervened in other motets, nor that he intervened in the same way. However, the analysis of the nature of differences would give us an idea of some of the changes that we could intro-

33 The basso continuo line reconstructed from Speer's re-elaboration has moreover been compared with the basso continuo lines found in other motets of Cozzolani. See COZZOLANI, Chiara Margarita. Motets. Robert L. Kendrick, ed. (Madison: AR Editions, 1998), which includes the modern edition of the Cantus part of the motet Quis mihi det calicem bibere Domini from Scherzi di sacra melodia.

34 We cannot rule out that in the passages entrusted exclusively to the continuo the part intended for the organist - which, according to Robert Eitner (apud Bellermann's catalogue of Berlin Gymnasium zum grauen Kloster) - should have been published as a "Part. in fol. (sic!)", could include some indications for its realization. See EITNER. Quellen-Lexikon, p. 91-92.

35 See KENDRICK. The Traditions of Milanese Convent Music, p. 231; KENDRICK. Celestial Sirens, p. 503. 
duce, if we deem it necessary, in the other motets of Cozzolani re-elaborated by Speer.

In conclusion, unless the basso continuo part of Chiara Margarita Cozzolani's edition reappears, any decision we make regarding the continuo line is destined to remain a hypothesis (more or less probable, more or less supported by external evidence), and therefore as such it will be presented in the critical edition.

For more than one reason, Kendrick has identified in Cozzolani's motet Quis mihi det calicem bibere? not only the most interesting composition of the entire collection, but also "one of the more balanced and impassioned pieces of the Milanese solo repertory", both for the meaning of its text (a meditation on the sufferings of Christ with references to the tools of the passion in line with the typical sensitivity of the spirituality of the time), and for its musical characteristics (among which the elaborate tripartite structure and the strict adherence to the meaning of the text). ${ }^{36}$ The same composition has also proved to be of interest with respect to the problem that is dealt with here, i.e. the reconstruction of the line of the basso continuo of Cozzolani's composition: in its final section, in fact, the surviving cantus presents three times a succession of rests of two breves, implying that, in those passages, the basso continuo should intervene, probably repeating or anticipating the motives already intoned - or destined to be repeated - by the voice (see the Appendix, bars 86-90 and 102-106).

Having ascertained that in the specific case of Speer's reworkings of Cozzolani's motets it seems possible to propose a plausible hypothesis of reconstruction of the bass line, it remains to ask what would be the most appropriate way to present the result of such an intervention within a critical edition. Regarding the possible choices of presentation of the musical text, given that the coincidence between the basso continuo line we find in Speer and that of the corresponding sections in the Cozzolani's compositions is in itself a hypothesis, I consider it appropriate that the bass line deduced by Speer (together with its figuring) should be reported in its entirety in the minor typographic body (see Ex. 2 and 3 and the Appendix). Moreover, since Cozzolani's bass line may slightly diverge from Speer's continuus in some points, and since in some places it also needs to be integrated, it would be even more appropriate to highlight these passages through a further graphical stratagem (for example, the use of square brackets that include the notes modified by the editor in Ex. 2).

To conclude, in the case of the six motets for solo voice and basso continuo by Chiara Margarita Cozzolani (1648) revised and published by Speer forty years later (1688) it has been ascertained that the removal of the elements added by Speer and the deconstruction of its reworking should allow a hypothetical reconstruction of the bass part of the motets presumably close to the last will of Chiara Margarita Cozzolani. Like any appropriation, also the reworking of Speer can be considered first and foremost as an act of love, thanks to which we can now recover some of the compositions of Chiara Margarita, for centuries considered unplayable and therefore fallen into oblivion.

36 See KENDRICK. Celestial Sirens, p. 383-387. For further reflections on the Milanese motet in the seventeenth century see also KENDRICK, Robert L. Feminized Devotion, Musical Nuns, and the 'New-Style' Lombard Motet of the 1640s. In Rediscovering the Muses: Women's Musical Traditions. Kimberly Marshall (ed.). Boston: Northeastern University Press, 1993, p. 124-139. 


\section{Appendix}

Chiara Margarita Cozzolani, Quis mihi det calicem bibere?

Hypothesis of reconstruction of the basso continuo (bb. 79-141) based on Daniel Speer's re-elaboration

\section{Quis mihi det calicem bibere?}

\section{Canto solo}
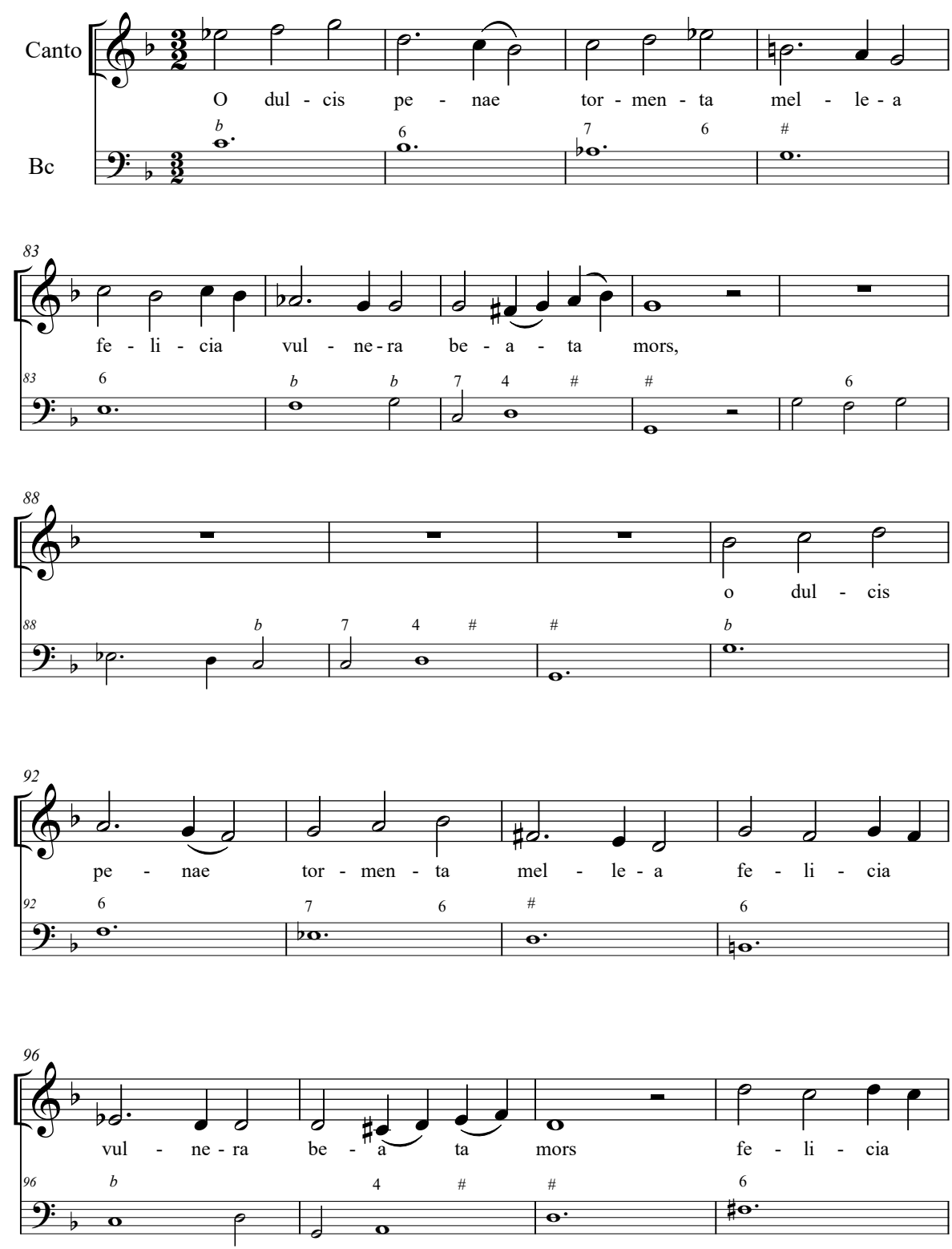

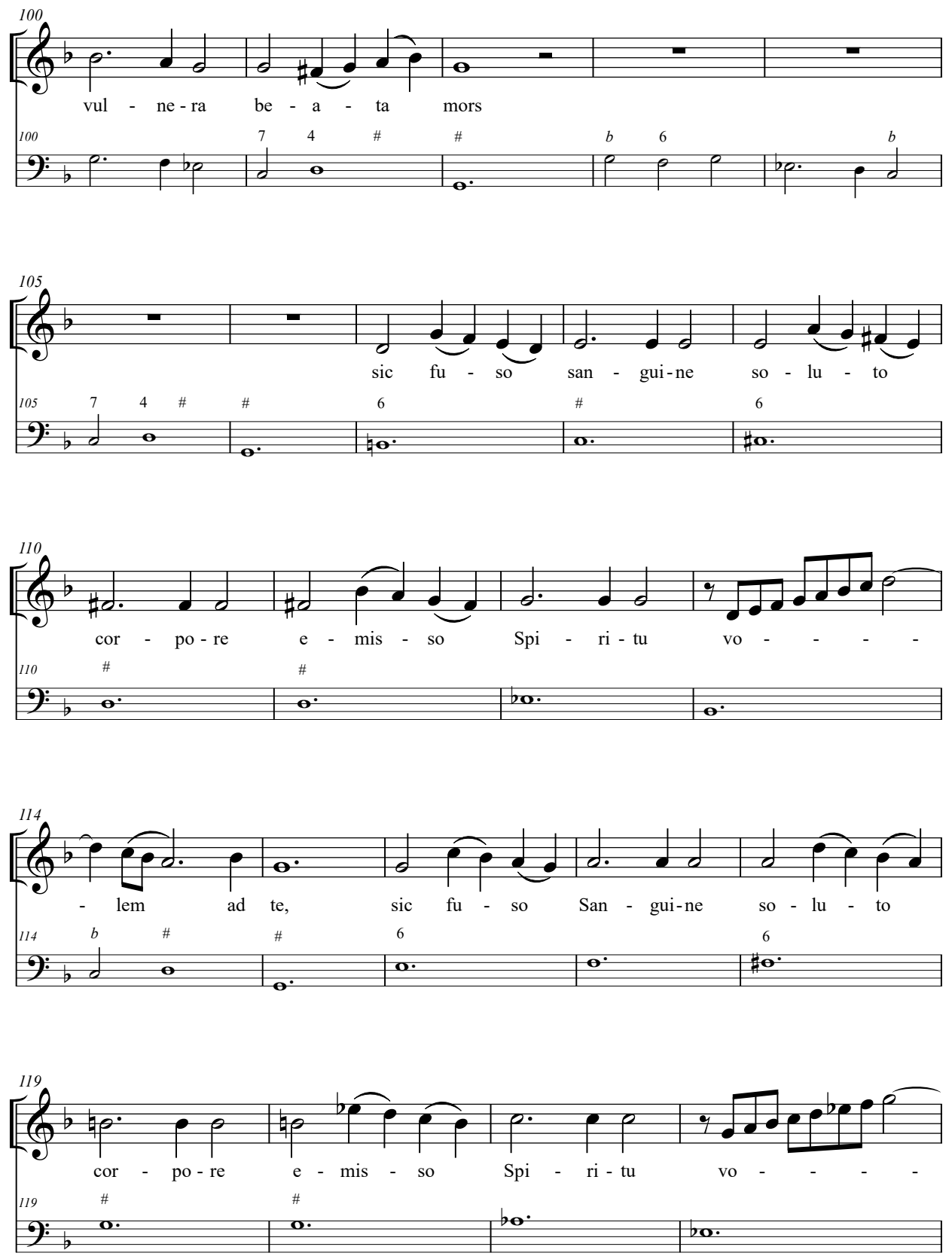

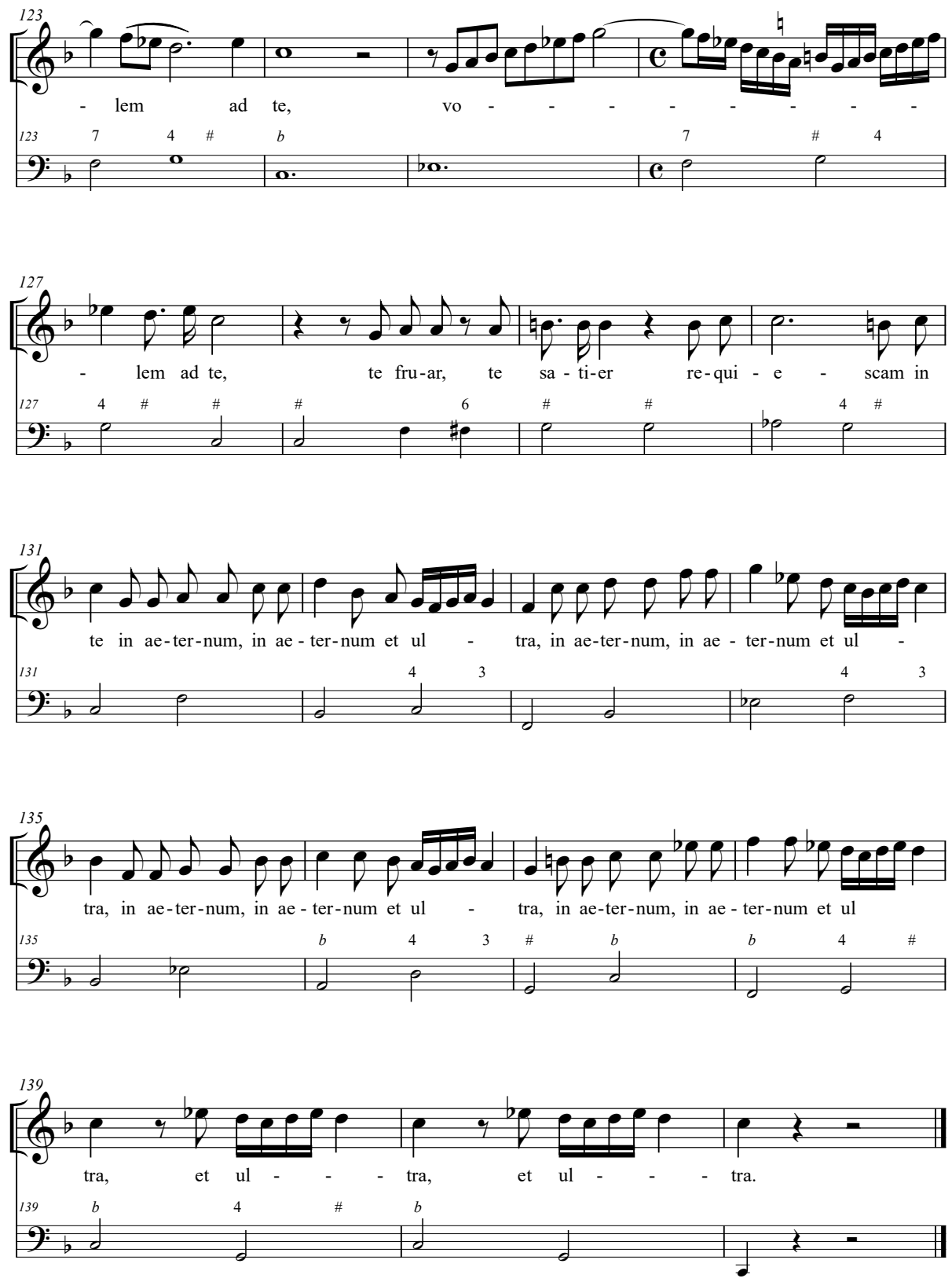


\section{Bibliography}

ARDEMANIO, Giulio Cesare. Musica a più voci (Milano, 1628). Composizioni per un'azione pastorale in onore di San Carlo Borromeo, Marina Toffetti (ed.). Pisa: ETS, 2012 («Diverse voci...», 11).

BACCIAGALUPPI, Claudio. Carissimi "farcito": esempi di ricezione e di diffusione nel Nord e nell'Est europeo. In L'opera musicale di Giacomo Carissimi. Fonti, catalogazione, attribuzioni. Atti del convegno internazionale di studi Roma, 18-19 novembre 2005. Daniele Torelli (ed.). Roma: Accademia Nazionale di Santa Cecilia, 2014 (L'arte Armonica. Serie III, Studi e testi, 14), p. 33-54.

BAROFFIO, Giacomo Bonifacio. Palestrina e il canto gregoriano: l'innodia. In Palestrina e la sua presenza nella musica e nella cultura europea dal suo tempo a oggi. Atti del II Convegno Internazionale di Studi Palestriniani. Lino Bianchi - Giancarlo Rostirolla (eds.). Palestrina: Fondazione G. P. da Palestrina - Centro Studi Palestriniani, 1991, p. 23-26.

BARTOVÁ, Jana. Philomela angelica Daniela Speera ako hudobno-historický, interpretačný a edičný problém. In Quo vadis musica aeterna? Zbornik príspevkov z muzikologickej konferencie, Bratislava, 24. september 2013. Bratislava: Orman, 2013, p. 22-28.

BELLINI, Amedeo. Il restauro architettonico. Milano: Mondadori, 1978.

BROGIOLO, Gian Pietro. Archeologia dell'edilizia storica: documenti e metodi. Como: New Press, 1988.

CARACI VELA, Maria. Intertestualità e arte allusiva. In La filologia musicale. Istituzioni, storia, strumenti critici. Lucca: Libreria Musicale Italiana, vol. II, 2009.

CARANDINI, Andrea. Storie dalla terra. Manuale di scavo archeologico. Torino: Einaudi, 2000 (1 ${ }^{\text {st }}$ ed.: Bari: De Donato, 1981).

CONTINI, Gianfranco. Filologia. In Breviario di ecdotica. Torino: Einaudi, 1990 (II reprint).

COZZOLANI, Chiara Margarita. Motets. Robert L. Kendrick, ed. (Madison: AR Editions, 1998).

DOGLIONI, Francesco. Stratigrafia e restauro: tra conoscenza e conservazione dell'architettura. Trieste: LINT, 1997.

EITNER, Robert. Biographisch-bibliographisches Quellen-Lexikon der Musiker und Musikgelehrten der christlichen Zeitrechnung bis zur Mitte des neunzehnten Jahrhunderts. Leipzig: Breitkopf \& Härtel, 1832-1905.

FRESCOBALDI, Girolamo. Liber secundus diversarum modulationum singulis, binis, ternis, quaternisque vocibus (1627), critical edition and reconstruction of the missing part by Marco Della Sciucca and Marina Toffetti (Monumenti Musicali Italiani, XXVI, Girolamo Frescobaldi, Opere Complete, XI). Milano: Suvini Zerboni, 2014.

HARRIS, Edward C. Principles of archaeological stratigraphy. London: Academic press, 1979.

INGEGNERI, Marco Antonio. Inni a 4 voci (Venezia, 1606). Marina Toffetti (ed.). Lucca: LIM, 2002 (Opera Omnia, Serie I, vol. VIII).

KALINAYOVÁ-BARTOVÁ, Jana. Daniel Speer and his Philomela angelica cantionum sacrarum. In Kalinayová-Bartová, J., Zajíček, P., eds. Daniel Speer (1636-1707): Philomela angelica cantionum sacrarum (1688), Musicalia Istropolitana 7/5. Bratislava: Ars Musica, 2014, p. IX-XVII. ISBN 978-80-971672-0-2.

KALINAYOVÁ-BARTOVÁ, Jana. Italian Musical Inspirations in Daniel Speer's Philomela angelica cantionum sacrarum collection. In Kalinayová-Bartová, J., Zajíček, P., eds. Daniel Speer (16361707): Philomela angelica cantionum sacrarum (1688), Musicalia Istropolitana 7/1. Bratislava: Ars Musica, 2016, p. IX-LI. ISBN 978-80-971672-1-9.

KALINAYOVÁ-BARTOVÁ, Jana. Philomela angelica Daniela Speera - k neznámemu dielu známeho hudobníka. Musicologica Brunensia, 51, 2016/2, p. 41-53. 
KENDRICK, Robert L. Chiara Magarita Cozzolani. In Grove², vol. 6, p. 636-637.

KENDRICK, Robert L. Feminized Devotion, Musical Nuns, and the 'New-Style' Lombard Motet of the 1640s. In Rediscovering the Muses: Women's Musical Traditions. Kimberly Marshall (ed.). Boston: Northeastern University Press, 1993, p. 124-139.

KENDRICK, Robert L. Celestial Sirens: Nuns and their Music in Early Modern Milan. Oxford: Oxford University Press, 1996.

KENDRICK, Robert L. I mottetti di Claudia Rusca. In Barocco Padano 3. Alberto Colzani - Andrea Luppi - Maurizio Padoan (eds.). Como: AMIS (Antiquae Musicae Italicae Studiosi), 2004, p. $425-445$.

KENDRICK, Robert L. The Traditions of Milanese Convent Music and the Sacred Dialogues of Chiara Margarita Cozzolani. In The Crannied Wall: Women, Religion and the Arts in Early Modern Europe. Craig A. Monson (ed.). Ann Arbor: University of Michigan Press, 1992, p. 211-234.

KENDRICK, Robert L. Traditions and Priorities in Claudia Rusca's Motet Book. In Female Monasticism in Early Modern Europe. An Interdisciplinary View. Cordula van Wyhe (ed.). Burlington: Ashgate, 2008, p. 97-124.

JEŻ, Tomasz. Danielis Sartorii Musicalia Wratislaviensia. Warsaw: Wydawnictwo Naukove Sub Lupa, 2017 (Fontes Musicae in Polonia, A/I).

LEDBETTER, Steven - STRAS, Laurie. Ingegneri, Marc'Antonio. In Grove ${ }^{2}$, vol. 12, p. 380-382.

MISCHIATI, Oscar. Indici, cataloghi e avvisi degli editori e librai musicali italiani dal 1591 al 1798. Firenze: Olschki, 1984.

PRAETORIUS, Michael. Syntagma musicum. Vol. 3, Wolfenbüttel: Holwein 1619.

Readings in the History of Music in Performance. Carol Mac Clinton (ed.). Bloomington: Indiana University Press, 1979.

SCHILDT, Maria. Gustav Düben at work. Musical repertory and practice of Swedish court musicians 1663-1690. Uppsala: Uppsala Universitet, 2014 (PhD. diss., University of Uppsala, 2014).

SEGRE, Cesare. Avviamento all'analisi del testo letterario. Torino: Einaudi, 1985.

TOFFETTI, Marina. Il testo nel tempo: le modifiche apportate allo Psalterium et Hymnarium del Tesoro della Cattedrale di Cremona sullo sfondo della prassi esecutiva del gregoriano tardo. Rivista Internazionale di Musica Sacra, 2003, 2, p. 123-148.

TOFFETTI, Marina. Inni da un Salterio-Innario cremonese. In Cantus fractus italiano. Un'antologia. Marco Gozzi (ed.). Hildesheim-Zürich-New York: Georg Olms, 2012 (Musica Mensurabilis, 4), p. 233-246.

TOFFETTI, Marina. L'impiego delle melodie liturgiche tradizionali nella polifonia del tardo Rinascimento: il caso degli inni di Marc'Antonio Ingegneri (Venezia, 1606). In Il canto piano nell'era della stampa. Atti del convegno internazionale di studi (Trento, Castello del Buonconsiglio - Venezia, Fondazione Levi, 9-11 ottobre 1998). Giulio Cattin - Danilo Curti-Feininger - Marco Gozzi (eds.). Trento: Provincia autonoma di Trento - Servizio Beni librari e archivistici, 1999, p. 161-177.

TOFFETTI, Marina. Restoring a masterpiece. Some remarks on the reconstruction of the missing part in Girolamo Frescobaldi's Liber secundus diversarum modulationum (Rome, 1627). Musica Iagellonica, 2013, vol. 7, p. 5-24.

WIERMANN, Barbara. Die Entwicklung vokal-instrumentalen Komponierens im protestantischen Deutschland bis zur Mitte des 17. Jahrhunderts. Göttingen: Vandenhöck \& Ruprecht, 2005 (Abhandlungen zur Musikgeschichte, 14).

WOLLNY, Peter. Studien zum Stilwandel in der protestantischen Figuralmusik des mittleren 17. Jahrhunderts. Beeskov: Ortus, 2016 (Forum Mitteldeutsche Barokmusik, 5). 
ZANARDI, Bruno. Il restauro: Giovanni Urbani e Cesare Brandi, due teorie a confronto. Milano: Skira, 2009. 
